\author{
Cadernos de \\ ESTUdOS LINGï̈ISTIICOS - (55.2), Campinas, Jul./Dez. 2013
}

\title{
IMAGENS DE SI NA TELA DO CINEMA: REFLEXÕES SOBRE O ETHOS FÍLMICO
}

\author{
CAROLINA ASSUNÇÃO E ALVES ${ }^{1}$
}

\begin{abstract}
RESUMO: Uma das funções do discurso fílmico, assim como dos outros tipos de discurso, é causar um determinado impacto sobre o público, ou seja, ele é portador de alguma dimensão argumentativa. Para isso, a instância de produção emprega estratégias dentre as quais é possível verificar a presença das provas retóricas. Uma delas é o ethos, que implica a construção de uma ou mais imagens de si por parte do enunciador, a fim de obter a adesão pretendida. No caso do filme narrativo de ficção, as circunstâncias determinantes da troca comunicativa chamam atenção para certas particularidades: a linguagem cinematográfica, o star system, os aspectos comerciais e dramáticos, as identidades envolvidas dentro e fora do mundo ficcional. O objetivo deste artigo é refletir sobre as possíveis configurações do ethos nesse gênero discursivo específico, com base principalmente nas categorias estabelecidas por Amossy (2006) e sob a perspectiva da teoria semiolinguística de Charaudeau (2001). A fim de poder melhor visualizar a aplicação das ideias propostas, será realizada uma análise do ethos no filme O Poderoso Chefão II (The Godfather Part II, 1974), de Francis Ford Coppola.
\end{abstract}

PALAVRAS-CHAVE: ethos - discurso fílmico - ficção

RÉSUMÉ: Parmi les fonctions du discours filmique, ainsi que d'autres types de discours, il y a le but de provoquer un impact sur le public, c'est à dire qu'il porte au moins une certaine dimension argumentative. Pour cela, l'instance de production emploie des stratégies parmi lesquelles il est possible de vérifier la présence des preuves rhétoriques. L'ethos implique la construction d'une ou plusieurs images de soi par l'énonciateur en vue d'obtenir l'adhésion souhaitée. Dans le cas du film narratif de fiction, les circonstances déterminant l'échange communicatif attirent l'attention à des particularités: le langage cinématographique, le star-system, les aspects commerciaux et dramatiques, les identités concernées à l'intérieur et à l'extérieur de l'univers fictionnel. L'objectif de cet article est de discuter les configurations possibles de l'ethos dans ce genre discursif spécifique, basée principalement sur les catégories établies par Amossy (2006) et du point de vue de la théorie semiolinguistique de Charaudeau (2001). Afin de pouvoir mieux visualiser l'application des idées proposées, il y aura une analyse de l'ethos dans le film Le Parrain II (The Godfather Part II, 1974), de Francis Ford Coppola.

MOTS-CLÉS: ethos - discours filmique - fiction

${ }^{1}$ Bolsista do Programa de Estágio Pós-Doutoral da Coordenação de Aperfeiçoamento de Pessoal de Nível Superior (Capes), ligada ao Laboratoire Communication et Politique do Centre National de la Recherche Scientifique (CNRS) - Paris, França (2012-2014). Mestre (2006) e Doutora (2011) em Linguística do Texto e do Discurso pela Faculdade de Letras da UFMG, com estágio doutoral de um ano na França (2008-2009 - bolsista da Capes ligada ao Centre d'Analyse du Discours da Université Paris 13). Bacharel em Comunicação Social com habilitação em Jornalismo pela Faculdade de Filosofia e Ciências Humanas da UFMG (2002). Professora licenciada do curso de Comunicação Social do Centro Universitário de Brasília (UniCEUB). CV Lattes: http://lattes.cnpq. br/4787241344336855 - carolinaassuncao@ig.com.br 
O ethos é a prova retórica artística (ARISTÓTELES, 2001, p.46) que corresponde ao caráter do orador apresentado no discurso para melhor influenciar a plateia (junto com as provas do pathos, centrado sobre as emoções a serem mobilizadas no auditório; e do logos, focado no uso do discurso para a demonstração persuasiva). Uma vez que resulta de determinada construção discursiva, essa imagem não é idêntica, equivalente à pessoa real do orador. Trata-se de uma representação que pode estar, por um lado, ligada às virtudes morais que culminam na credibilidade do locutor perante o alocutário; por outro, relacionada à adequação da fala do orador ao papel social que desempenha no momento da enunciação, o que potencializa a capacidade de persuasão.

O discurso fílmico, assim como os outros, é dotado de, no mínimo, dimensões argumentativas:

L'argumentation dans le discours s'attache aussi bien aux discours qui visent explicitement à agir sur le public, qu'à ceux qui exercent une influence sans se donner pour autant comme une entreprise de persuasion. ${ }^{2}$ (AMOSSY, 2006, p.33).

Causar um determinado impacto sobre o público e, portanto, lançar mão de estratégias que permitam o alcance desse objetivo é algo que reside entre as intenções do(s) autor(es) de um projeto de fala. Na análise do discurso fílmico, o emprego das provas retóricas também pode ser identificado, no sentido de melhor compreender efeitos prováveis a serem obtidos. No entanto, há que se observar as particularidades do dispositivo audiovisual, em que imagens, sons e outros elementos da linguagem cinematográfica atuam conjuntamente com a parte textual, a coletividade da criação e circunstâncias situacionais específicas.

A meta deste artigo $^{3}$ é examinar o ethos no filme narrativo de ficção. Nesse sentido, serão apresentadas algumas considerações sobre formas a serem assumidas por tal prova retórica no universo do referido gênero discursivo. A fim de verificar sua aplicabilidade, será elaborada uma subsequente observação do ethos no filme O Poderoso Chefão II (The Godfather part II, 1974), de Francis Ford Coppola. A pesquisa se insere no domínio da análise do discurso enquanto "[...] disciplina que estuda as produções verbais no interior de suas condições sociais de produção. Essas são consideradas como partes integrantes da significação e do modo de formação dos discursos”. (PAVEAU; SARFATI, 2006, p.202)

Compartilhamos a perspectiva da teoria semiolinguística de Charaudeau (2001), para quem todo ato de linguagem consiste numa encenação que envolve a interação entre sujeitos psicossociais, na qual cada participante tem uma expectativa de significação particular. Essa encenação é formada pelo circuito externo ou situacional (do fazer), onde se localizam as circunstâncias e sujeitos da

${ }^{2}$ Tradução livre: A argumentação no discurso é focada tanto nos discursos destinados explicitamente a agir sobre o público, como naqueles que exercem influência sem contudo terem se estabelecido como um projeto de persuasão.

${ }^{3}$ Artigo produzido a partir de resultados obtidos com a tese de doutorado intitulada Dimensões argumentativas do discurso filmico: projeções retóricas na tela do cinema, defendida na Faculdade de Letras da Universidade Federal de Minas Gerais (FALE/UFMG) em 19 de agosto de 2011. 
produção e recepção do discurso; e pelo circuito interno ou discursivo (do dizer), que dá lugar à materialização da enunciação.

Sujeito Comunicante e Sujeito Interpretante, seres empíricos (históricos, psicossociais), estabelecem um contrato de comunicação em que o Comunicante aciona um Sujeito Enunciador em virtude da imagem de Sujeito Destinatário que ele projeta a respeito do Interpretante. Nesse quadro, Enunciador e Destinatário são seres de fala, ou seja, que existem apenas no circuito interno. Tudo isso ocorre diante de determinadas condições situacionais e discursivas formadas por três componentes: o comunicacional ou as circunstâncias materiais do ato de linguagem; o psicossocial, relativo aos estatutos psicológicos e sociais reconhecidos pelos parceiros entre si; o intencional ou conhecimento a priori entre os sujeitos envolvidos, que direciona a finalidade do discurso.

Quanto à questão da argumentação, nosso objeto de estudo é vislumbrado de acordo com a retórica clássica aristotélica, a teoria da argumentação desenvolvida por Olbrecth-Tyteca e Perelman (2008) e a argumentação no discurso, segundo Amossy (2006). Dentre as reflexões desses autores está a categoria do ethos, a ser detalhada nos itens que se seguem.

\title{
O ethos
}

A respeito do ethos, como explica Eggs (1999, p.32),

\begin{abstract}
Nous nous trouvons donc, dans la Rhétorique d'Aristote, devant deux champs sémantiques opposés liés au terme ethos: l'un, au sens moral et basé sur l'épieíkeia, englobe des attitudes et des vertus comme honnêteté, bienséance ou équité; l'autre, au sens neutre ou 'objectif' de héxis, rassemble des termes comme habitudes, moeurs et coutumes ou caractère. [...] ces deux conceptions ne s'excluent pas, mais constituent tout au contraire les deux faces nécessaires de toute activité argumentative. ${ }^{4}$ (Grifos do autor.)
\end{abstract}

Algumas dimensões extraverbais do orador que fazem parte do ethos são: a reputação ou imagem anterior; o estatuto e o prestígio, herdados dos ancestrais ou devido às funções que exerce; as qualidades próprias, a personalidade; o modo de vida, ou seja, os exemplos dados via comportamento. Além dos traços de subjetividade, a inscrição do sujeito no discurso é ativada pelo gênero, pois o orador se insere numa cena de enunciação cujo gênero discursivo define papéis previamente. $\mathrm{O}$ ethos também se alimenta dos estereótipos da época, uma vez que a imagem do locutor está ligada aos modelos sociais.

${ }^{4}$ Tradução livre: Encontramo-nos, assim, dentro da Retórica de Aristóteles, diante de dois campos semânticos opostos ligados ao termo ethos: um, no sentido moral e baseado na épieíkea, engloba as atitudes e as virtudes como honestidade, benevolência ou equidade; outro, no sentido neutro ou 'objetivo' de héxis, remete a termos como hábitos, morais e costumes ou caráter. [...] essas duas concepções não se excluem, mas pelo contrário, constituem as duas faces necessárias a toda atividade argumentativa. 
Na análise argumentativa do discurso, Amossy (2006) esclarece que a imagem de si construída pelo orador no momento da enunciação não exime outra imagem dele, também relevante para a troca comunicativa: aquela da qual o auditório já está munido, e que é, portanto, anterior à representação de si que o locutor tenta mostrar quando se reporta ao alocutário. A autora considera a existência de dois tipos de ethos:

- O ethos prévio, composto pelas impressões acerca do orador que o auditório já possui antes da enunciação em questão, procedente do nível situacional e do acesso da plateia a um interdiscurso que fornece dados para a elaboração dessas impressões (estatuto institucional, estereótipo que circula sobre a pessoa do orador etc.).

- O ethos discursivo, que emerge no instante da enunciação, atualizado no discurso pelo locutor em tempo real, enquanto ele se dirige ao alocutário, seja face a face ou virtualmente. É determinado pela definição dos papéis conforme a cena genérica e a imagem de si que o locutor projeta no discurso.

Assim, para acessar o ethos de um determinado discurso, é preciso levar em conta a imagem social do orador (nacionalidade, profissão, sexo etc.); a imagem singular do orador (como ele é apreendido enquanto indivíduo no momento da troca); e a possibilidade de essa imagem ser composta por identidades diferentes e, às vezes, contraditórias (AMOSSY, 2006, p.82).

O cruzamento entre as informações distribuídas pelos ethos prévio e discursivo fica submetido a dois aspectos fundamentais: a capacidade do enunciador de lançar mão estrategicamente da reputação que possui, seja para endossá-la, refutá-la ou modificá-la; e a aptidão do coenunciador para usar o conhecimento prévio acerca do enunciador na interpretação do discurso transmitido. Essa rede de interações é o que determina o caráter persuasivo da argumentação exposta via ethos, o qual pretendemos verificar no filme narrativo de ficção.

\section{As múltiplas faces do ethos no cinema}

No filme narrativo de ficção, as imagens de si resultantes dessa complexa enunciação conduzem à observação das representações que envolvem o diretor, o roteirista, os atores, as personagens, o gênero etc. É preciso estudar como essas imagens de si apropriam-se da linguagem cinematográfica e de que maneira orientariam o público retoricamente para, em uma conjuntura dada, influenciar pensamentos, alterar estados de ânimo ou inspirar condutas.

O gênero discursivo estudado neste trabalho, filme narrativo de ficção, divide-se ainda em subgêneros (chamados gêneros fílmicos nos estudos cinematográficos), tais como drama, terror, comédia, romance, épico, ficção científica, ação, suspense etc. - pode ainda acontecer uma mistura de dois ou mais deles. Observamos a princípio que, para cada filme, a instância de enunciação incorpora um "ethos típico" que toma forma com o desenvolvimento da trama, dos diálogos, do desempenho dos atores, do figurino, entre outros.

Quando escolhe um filme, o espectador já tem uma noção de aspectos gerais comuns ao(s) respectivo(s) subgênero(s), e em função disso cria uma expectativa que poderá ou não ser correspondida. Tal expectativa faz parte do ethos prévio, 70 
composto pela questão do gênero e construído também com as informações sobre o filme e os responsáveis por ele. Esses dados chegam ao público antes do contato direto, por meio de sinopses, críticas, resenhas, entrevistas de lançamento, reportagens etc. Já o ethos discursivo é determinado pelas trocas com o Sujeito Interpretante no instante em que este assiste à peça cinematográfica, conforme as condições e restrições do contrato de comunicação para esse tipo de encenação do ato de linguagem.

Numa primeira aproximação da categoria do ethos fílmico, visualizamos o diretor. A iniciativa do filme pode partir dele mesmo ou de outra fonte, como uma empresa de produção audiovisual ou uma instituição pública, entre outros. Porém, ainda que o cineasta execute o trabalho sob encomenda, com o auxílio de uma equipe e a partir de um roteiro escrito por outro indivíduo, baseado em um romance literário ou em um texto elaborado especificamente para o cinema, o resultado final é normalmente orientado pela identidade, pelas escolhas e pela maneira como o diretor pretende materializar o roteiro.

Nos casos de adaptações de obras literárias para o cinema, não se pode ignorar que elementos do ethos do romance também passam a fazer parte do ethos da enunciação cinematográfica, por pelo menos duas vias: 1) o contato do diretor com a narrativa original e autoria, para a produção do filme; 2) e o alcance (de grau variável) do texto literário entre os espectadores.

Basta lembrar que um mesmo texto pode servir como base para filmes diferentes, em função das opções daquele que assume a cadeira de diretor. O romance irlandês Drácula, de Bram Stoker (1897), é um exemplo. Ao longo da história do cinema, o livro deu origem a centenas de versões fílmicas, dentre as quais: Nosferatu le vampire (1922), de Friedrich Murnau, que foi a primeira adaptação (livre) para o cinema; e Bram Stoker's Dracula (1992), de Francis Ford Coppola, conhecido pela tentativa de máxima fidelidade ao livro.

Um estudo dos circuitos externo/situacional (período histórico, contexto, subjetividades envolvidas, outras condições de produção) e interno/discursivo (estrutura narrativa, emprego da linguagem cinematográfica) seria suficiente para compreender as variações entre as duas versões, embora elas possuam a mesma fonte literária e pontos em comum. Nesse contexto, a equipe de produção do filme se encarrega essencialmente de "dar vida" às decisões do realizador cujo papel é determinante na construção do sentido. Torna-se necessário um olhar atento sobre a composição desse ethos no discurso: as imagens social e singular do cineasta, assim como as diferentes identidades assumidas por ele.

Além da variedade de códigos semiológicos que compõem a linguagem cinematográfica, a multiplicidade do ethos fílmico revela-se na existência de dimensões de um mesmo ethos que se desdobra em camadas, dentre as quais podemos perceber alguns níveis. O primeiro diz respeito ao ethos prévio/discursivo do cineasta, como dissemos nos parágrafos anteriores. O segundo nível refere-se às personagens, que entram em contato direto com o público na sala de cinema.

A composição do ethos da personagem é formada principalmente pela performance do ator (uma mistura de atuação, maquiagem e figurino), complementada por outros itens da abordagem técnica cinematográfica (cenário, 
enquadramentos, movimentos de câmera, luzes e efeitos sonoros usados na valorização das ações e expressões). Como resultado, cada papel representado por um ator no decorrer da trama exibe uma imagem de si, cujas qualidades dialogam com o espectador na construção da interpretação. A partir das informações fornecidas pelo filme, o público poderá tirar conclusões e se posicionar com relação ao que a obra lhe diz.

Outro nível de composição do ethos fílmico seria vislumbrado ainda por trás das personagens, na presença dos atores enquanto seres reais. Ao dar corpo às entidades ficcionais, eles participam do circuito interno ou nível discursivo, e integram o Sujeito Enunciador colocado em ação pelo Sujeito Comunicante. Mas o discurso fílmico não é apreendido apenas interna e isoladamente, ele está inserido numa sociedade e dialoga com os interdiscursos circulantes nesse meio, do qual também fazem parte os enunciados referentes ao star system cinematográfico materiais midiáticos relativos ao cinema e às celebridades, tais como reportagens, biografias, entrevistas. Ou seja, mesmo que esteja a serviço do projeto de comunicação de outro indivíduo, é possível que componentes da identidade real do ator cheguem a se confundir com a personagem em algum momento.

Uma imagem do indivíduo-ator surgiria, assim, como prolongamento imediato da imagem da personagem do filme e vice-versa, reforçadas pela mídia e pela indústria cultural, especialmente no caso de filmes comerciais. Contudo, como destaca Amossy (1991, p.144), essa imagem da “(...) star ne se rapporte cependant ni à la personne réelle, ni au personnage du film; bien plutôt à un être hybride qui tient des deux"5. Essa imagem constitui uma espécie de espectro ético que margeia o ethos fílmico, cujos efeitos sobre o ato de linguagem dependerão sempre da interação obra/público, a variar de caso a caso.

$\mathrm{O}$ espectador pode, por exemplo, adotar uma postura " $\mathrm{x}$ " em relação ao filme ou à(s) tese(s) identificada(s) na narrativa, influenciado por traços éticos do ator que ele confere consciente ou inconscientemente à personagem. Tais possibilidades retóricas manifestadas no discurso fílmico auxiliam, finalmente, no reconhecimento das dimensões argumentativas e de como elas se instauram na prova do ethos (ethos prévio ou conhecimento anterior sobre o enredo, as personagens, os atores e o diretor + ethos discursivo ou imagens de si construídas ao longo da narrativa). $\mathrm{O}$ método da análise argumentativa associada à teoria semiolinguística permite recuperar dados situacionais e discursivos que propiciam o levantamento de hipóteses pertinentes à enunciação estudada.

Existem trocas comunicativas em que o espectador assiste ao filme desprovido dessas referências, ou seja, não conhece o diretor, tampouco os atores, nem tem maiores informações sobre o discurso com o qual entra em contato. Poder-se-ia afirmar que esse tipo de público estabelece uma relação de outra ordem com a obra, o que não impede a coenunciação com acesso às dimensões argumentativas do discurso. $\mathrm{O}$ ethos que emerge dessa troca resulta de uma combinação entre as disposições do coenunciador (fatores psicossocioculturais) e o ethos discursivo,

${ }^{5}$ Tradução livre: não se refere, no entanto, nem à pessoa real, nem à personagem do filme; mas a um ser híbrido que abriga ambos. 
cuja constituição carrega contribuições do ethos prévio, ainda que desconhecido da instância de recepção, pois ele se pronuncia na materialidade discursiva.

Mas não é somente o ethos que define as dimensões argumentativas e a orientação do espectador; assim como em qualquer discurso, ele atua, pelo menos, em conjunto com as provas retóricas do logos e do pathos, que também aparecem com intensidade variável. As imagens de si do ethos fílmico são associadas, por exemplo, à manipulação dos sentimentos das personagens para, em última instância, emocionar o espectador e movê-lo diante da narrativa, o que torna necessário tentar compreender a configuração das paixões na elaboração do discurso fílmico (pathos). Além disso, o público pode identificar raciocínios lógicos e optar por aderir ou não a determinadas propostas do filme, que lhes pareçam demonstradas como verdadeiras via discurso (logos). Como nosso objetivo é examinar mais detalhadamente a prova do ethos, passemos à aplicação dessa categoria numa análise do filme $O$ Poderoso Chefão II, de Francis Ford Coppola.

\section{O ethos fílmico em O Poderoso Chefão II}

Para uma análise do ethos em O Poderoso Chefão II, é importante entender minimamente o quadro do contrato de comunicação em que ele se insere ${ }^{6}$. Embora tenha sido realizado, distribuído e exibido como uma única peça cinematográfica, ele faz parte de uma sequência de três filmes dirigidos por Coppola nos anos de 1972, 1974 e 1990. Os roteiros foram escritos em coautoria dele com o escritor Mario Puzo, autor do livro best seller que deu origem ao primeiro filme. Todas as três partes da trilogia foram financiadas e distribuídas pela Paramount Pictures.

O componente comunicacional ou as circunstâncias materiais linguageiras dizem respeito ao universo cinematográfico comercial: a princípio, produção de narrativas audiovisuais para a projeção sobre telas em salas de cinema nas quais se paga pela entrada - fins lucrativos que, contudo, não neutralizam a presença e relevância das intenções relativas aos aspectos expressivo, dramático, estético. Quanto ao componente psicossocial, localizam-se na instância de produção: o estúdio Paramount, financiador do projeto; os roteiristas Mario Puzo e Francis Ford Coppola (diretor), a equipe de produção do filme.

Os objetivos desse grupo (componente intencional do contrato de comunicação) variam entre lucro e necessidade de criação e expressão, de reconhecimento e status, entre outros. Observamos que após o inesperado grande sucesso do primeiro filme, Coppola teve mais liberdade e poder de decisão sobre a segunda parte, criada para dar continuidade aos rendimentos financeiros. $\mathrm{Na}$ anterior, o então jovem cineasta estava sempre submetido às ordens dos produtores da Paramount, as quais combateu e conseguiu flexibilizar em alguns aspectos.

${ }^{6}$ Além dos trabalhos de Delorme (2007) e Duncan (2010), entre outras leituras, foram utilizadas informações do vídeo A obra-prima que quase não existiu, do DVD Bônus produzido para a caixa de DVDs O Poderoso Chefão - The Coppola Restoration pela Paramount Pictures (2008 - vide Referências bibliográficas); assim como os comentários de Coppola em voice over sobre os filmes da trilogia. 
$\mathrm{Na}$ instância de recepção temos o público, sempre variável, acessível apenas em estudos específicos que não nos competem neste artigo.

É preciso conhecer também a estrutura narrativa na qual o filme se insere. O enredo conta como pai e filho assumem o comando de duas gerações da máfia ítalo-americana nos Estados Unidos. São mostrados os primeiros anos de vida de Vito Andolini na Sicília, em meio às ameaças entre famílias que culminam na morte de seus pais e irmão, em seguida a fuga para os EUA, ainda criança. Na América do Norte dos anos 1920 e 1930, Vito Corleone torna-se o temido e respeitado Don Vito, o Padrinho interpretado por Robert De Niro, numa região de Nova Yorque habitada por imigrantes italianos Little Italy (Pequena Itália), também conhecida como Hell's Kitchen (Cozinha do Inferno).

Paralelamente, é mostrada a ascensão de Michael como o segundo Don Corleone, chefe de negócios que envolvem cassinos de jogos e políticos importantes. Assiste-se à transformação do jovem Michael Corleone, um militar em conflito com os negócios inescrupulosos da família, em novo Padrinho, até o próprio declínio. O papel é interpretado por Al Pacino, como no primeiro filme.

A ascensão e o domínio de Vito Corleone sobre os negócios comandados pela máfia ítalo-americana são contraponto à atuação de Michael como chefe desse mesmo grupo, que está ainda mais poderoso, com negócios expandidos para Las Vegas e Cuba, além da circulação pela alta classe do poder político norte-americano. Ao mesmo tempo, a maneira como pai e filho conduzem a própria história permite compreender o porquê de o fim da vida deles ter tomado rumos tão distintos, embora ocupassem o mesmo posto (familiar, social, político etc.).

Antes de morrer, momento mostrado no primeiro filme da trilogia, Vito é um homem rodeado por atenção e carinho dos parentes, enquanto Michael, cuja morte é abordada no terceiro filme, é consumido pela solidão do isolamento construído por ele mesmo. Ele implode a família em busca de poder, chega a matar um cunhado no primeiro filme e um irmão no segundo. Além disso, sente-se responsável pela morte da filha, atingida acidentalmente num atentado contra ele, no terceiro filme.

Com base nessas informações e em virtude das limitações deste espaço, concentraremos o estudo do ethos fílmico nas imagens de si projetadas pelos dois protagonistas, Vito e Michael Corleone, e pelo roteirista e diretor Coppola. Os principais elementos da linguagem cinematográfica a serem levados em conta serão a direção e a atuação dos atores, mas outros também serão apontados quando relevantes.

Antes de partirmos para a análise, convém apresentar alguns esclarecimentos sobre os elementos da linguagem cinematográfica mencionados acima. Durante a filmagem, o diretor instrui os atores sobre como ele quer mostrar cada personagem, e se ocupa de enquadrar essas performances conforme as propostas da narrativa. De acordo com Martin (1990), a câmera coloca em evidência as expressões gestuais associadas ao código verbal. O intérprete é responsável por imprimir no próprio corpo (e, consequentemente, exprimir) a identidade e as emoções dessas 
personalidades ficcionais. "What the actor does, I suggest, is to give blood to the fantasies of the audience" 7. (ALEXANDER, 1972, apud DUNCAN, 2010 p.49).

Com base nas reflexões de Mukarovsky (1966 apud COSTA, 1989, p.236-238), Costa refere-se ao ator como estrutura parcial do texto do filme em movimentos vocais, gestuais e ações em diálogo com o espaço cênico. Para se compreender as contribuições do ator para o resultado, é preciso investigar as relações entre o desempenho dele durante a encenação e os outros componentes da linguagem cinematográfica. As mesmas observações também são pertinentes no que diz respeito ao nosso trabalho de apreensão do ethos discursivo das personagens, e por isso serão instrumentos importantes para a análise.

\section{Ethos de Vito Corleone}

Na sequência inicial que se passa na Sicília, durante a infância de Vito Andolini, as cenas filmadas são luminosas, com branco "estourado". O azul claro do céu é bem marcado, as imagens aparecem superexpostas à luz, o que pode remeter ao clima da ilha, às pequenas aldeias cujos moradores vivem em contato com a natureza, as montanhas, o Mediterrâneo e, ainda, à ideia do passado mostrado em flashback.

Essa atmosfera está ligada também à rusticidade do povo na postura, no modo de andar, de conversar, de lidar visceralmente com paixões como a vingança e a dor do luto. O tom é dramático, aos moldes sicilianos: falas exaltadas, expressões gestuais e faciais bem marcadas, ambientações simplórias. Nesses primeiros momentos, o filme apresenta as influências ancestrais na formação da personalidade do menino (ethos discursivo do protagonista), no início de uma vida ditada pelas vozes do amor familiar e do instinto de sobrevivência.

O jovem Vito é interpretado por Robert De Niro, que mantém traços do protagonista mais maduro representado por Marlon Brando no filme anterior: " [...] il [Brando] se met des Kleenex dans la bouche pour ressembler à un bulldog, prend une voix cassée, mâchouille, baragouine et se transforme en vieux Sicilien [...] un acteur qui fait travailler les mains, la bouche, les yeux, le cou, dans un tourbillon incessant". ${ }^{8}$ (DELORME, 2007, p.72) O olhar marcante, a voz sussurrada, o ar misterioso e irônico, oscilante entre a ternura e a crueldade, as atitudes friamente calculadas. Ao longo da narrativa, o trabalho do ator desenha um perfil ao mesmo tempo heroico e perigoso.

Coppola usa atributos pessoais de De Niro para explicar a escalação: bonito, de porte másculo, sedutor, em sintonia com as características necessárias à imagem jovem da personagem. Para o cineasta, De Niro lembrava Rudolph Valentino, ator italiano que emigrou para os Estados Unidos no início do século XX, conhecido pela fama de conquistador e por ter sido dançarino e gigolô antes de atuar. A forma

\footnotetext{
${ }^{7}$ Tradução livre: O que o ator faz, eu suponho, é dar sangue às fantasias do público.

${ }^{8}$ Tradução livre: ele coloca Kleenex na boca para se parecer com um buldogue, e se transforma em velho Siciliano [...] um ator que trabalha as mãos, a boca, os olhos, o pescoço, num turbilhão incessante.
} 
física como Coppola imaginava o protagonista remetia à virilidade do provedor e, ao mesmo tempo, à sedução do negociador.

As falas de Vito na cena que antecede a transformação em Don Corleone demonstram essa caracterização. Don Fanucci, mafioso que domina a região e amedronta os comerciantes locais, cobra 600 dólares de Vito e seus dois sócios para que o empreendimento dos três amigos não enfrente obstáculos. Vito é o único do trio que não concorda em se submeter à extorsão. Durante a refeição, eles discutem o assunto:

Vito: Garanto que ele vai aceitar o que vou lhe dar. Vou entrar num acordo com ele.
Deixem isso comigo. Vou cuidar de tudo. Nunca minto para meus amigos. Amanhã
vocês vão falar com Fanucci. Digam que vão pagar o que ele pedir. Não discutam
com ele. Depois eu vou e entro num acordo com ele. Mas não entrem em discussão,
já que ele é tão esperto como vocês.
Clemenza: Como você fará para ele aceitar menos?
Vito: Isso não é da sua conta. Lembrem-se que fiz um favor a vocês. Está
combinado??

Vito assume o controle como estrategista, protetor, amigo leal e o único com coragem para enfrentar Fanucci. Em troca, deseja ser lembrado pelo favor concedido aos companheiros. Essa cena apresenta uma primeira definição da identidade que será assumida por Don Vito Corleone e colocada em prática logo a seguir. O corte rápido entre os planos fechados em cada um dos três participantes da conversa confere o ritmo e a emoção que anuncia o tom de ação e suspense da próxima sequência.

Após uma tentativa fracassada de negociação civilizada (embora plena de cinismo e ironia) com o temido Mão Negra, Corleone persegue-o silenciosamente pelos telhados da vizinhança, enquanto a vítima caminha nas ruas do bairro durante a procissão de San Genaro. O algoz prepara a tocaia para assassinar Fanucci na porta de casa, não sem antes encará-lo friamente nos olhos, deixar claro de quem é a palavra final nesse acerto de contas. Eliminado o rival, Vito passa a ser respeitado pelos vizinhos, que o procuram cada vez mais para interceder na resolução de conflitos. Ele se apropria desse prestígio para acumular dívidas de gratidão em benefício próprio, e construir uma rede de troca de favores que lhe confere poder.

\footnotetext{
${ }^{9}$ As citações de diálogos e as declarações de Coppola que aparecem sem referência neste artigo foram retiradas das legendas em português disponíveis na caixa de DVDs O Poderoso Chefão - The Coppola Restoration, já mencionada na nota 5 e listada entre as Referências bibliográficas. 


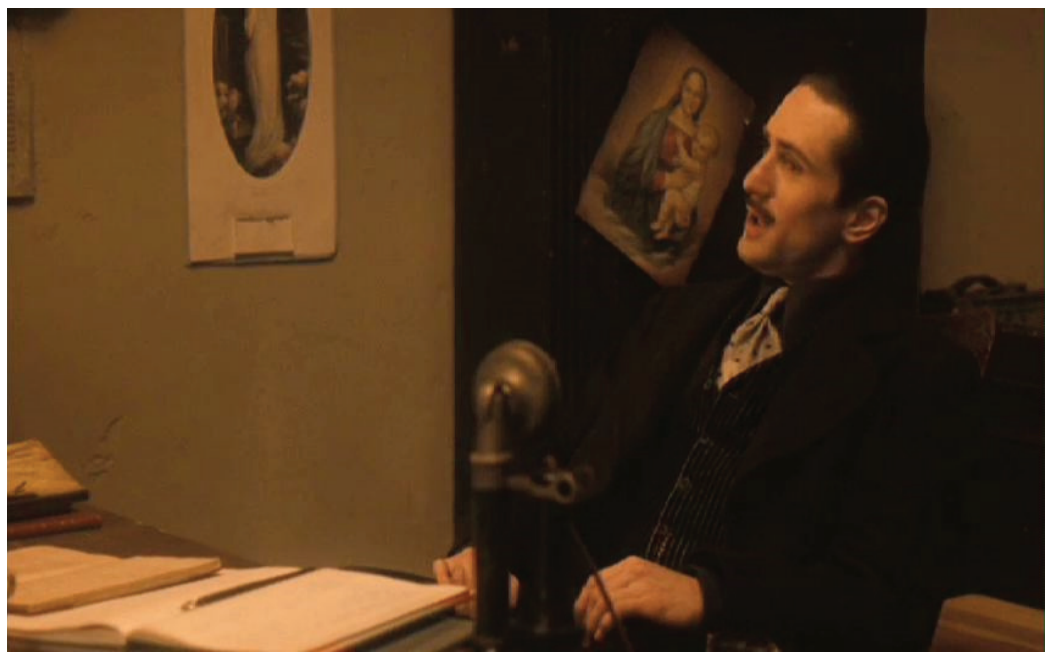

O jovem Don Corleone

A maneira como a vida de Vito Corleone é narrada e a materialização na performance de De Niro permitem identificar alguns componentes desse ethos discursivo: por um lado, astúcia, força, coragem, meticulosidade, ambição, diplomacia e frieza estratégica; por outro, solidão, obstinação pela reconstrução da família perdida na infância, forte instinto de proteção dos parentes e dos aliados, lealdade aos amigos e sede de vingança. Até o início da maturidade, a personalidade e, consequentemente, o ethos de Don Vito varia entre o calculismo e as manifestações passionais.

\section{Ethos de Michael Corleone}

Michael Corleone aparece na história como o preferido, considerado pelo pai como o herdeiro apto a substituí-lo no comando da família e dos negócios. Talvez em virtude desse tratamento diferenciado, ele acaba por se tornar o filho insolente que coloca os interesses próprios à frente dos da família. Prefere entrar para o serviço militar a se unir ao pai nas transações da máfia e, durante muito tempo, nega qualquer tipo de identificação com as operações suspeitas do círculo familiar. No entanto, a crescente instabilidade das relações entre as famílias mafiosas e a consequente tentativa de assassinato de Vito Corleone, no primeiro $O$ Poderoso Chefão, despertam em Michael os valores latentes da educação siciliana, e levam-no a atender a vontade do pai, assumindo o controle.

Observamos um traço do ethos da personagem na música de cena da festa de primeira comunhão do filho de Michael nos minutos iniciais do filme. Após anunciar doação financeira da família Corleone a uma universidade, o Senador Pat Geary apresenta a homenagem que será feita a Michael pelo coral The 
Sierra Boys Choir. Os meninos cantam Mr. Wonderful (Sr. Maravilhoso), que fica como background até o fim da sequência, com a seguinte estrofe:

\author{
Why this feeling? \\ Why this glow? \\ Why the thrill when you say hello? \\ It's a strange and tender magic you do. \\ Mister Wonderful, that's you. ${ }^{10}$
}

A representação de Don Corleone remete a uma imagem envolta por estranha e terna magia, como diz a letra da canção. Porém, a aura quase religiosa do líder mafioso construída pelo pai de Michael ganha novo tratamento por um homem dominado pela ideia do poder a qualquer custo e pela paranoia. Em nome da necessidade de autoafirmação como aquele que dita as regras, Michael torna-se capaz de descartar o apoio do homem mais confiável da família (o consigliere e irmão afetivo Tom Hagen), de agredir a esposa Kay, e, finalmente, de proferir a sentença de morte do próprio irmão biológico Freddo.

Michael est une figure tragique. Avec l'autorité naturelle du chef, il impose ses désirs en homme libre. Et pourtant tout cela lui pèse. Le regard pensif, le dos écrasé par les responsabilités, il porte come un fardeau un destin qui le dépasse. La valse triste composée par Nino Rota scande sa transformation en monstre de guerre: il avance à l'aveugle, dans l'ombre du père, parce qu'il semble de tout temps “avoir été fait pour ça". D'un Corleone à l'autre, au gré des vendettas, nous accompagnons la famille de l'intérieur comme un îlot sicilien dérivant tragiquement au-dessus des tables de la Loi $^{11}$.

(DELORME, 2007, p.23)

\footnotetext{
${ }^{10}$ Tradução livre: Por que esse sentimento?

Por que esse brilho?

Por que a emoção quando você diz olá?

É uma magia estranha e terna que você faz.

Senhor Maravilhoso, é você.
}

${ }^{11}$ Tradução livre: Michael é uma figura trágica. Com a autoridade natural do chefe, ele impõe seus desejos de homem livre. No entanto, tudo isso pesa sobre ele. O olhar pensativo, o dorso esmagado pelas responsabilidades, ele carrega como um fardo um destino que o transcende. A valsa triste composta por Nino Rota pontua sua transformação em um monstro de guerra: ele avança às cegas, à sombra do pai, porque lhe parece "ter sido feito para isso". De um Corleone a outro, por meio das vinganças, acompanhamos a família por dentro, como uma ilhota siciliana tragicamente à deriva sobre as mesas da Lei. 


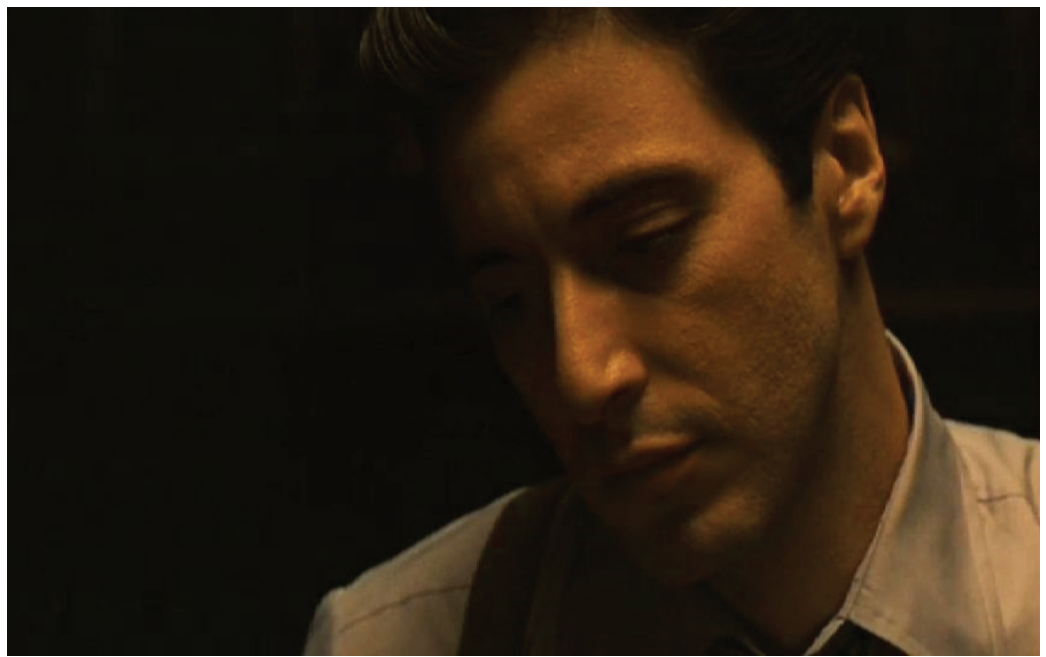

Michael, o segundo Don Corleone

Esse percurso também pode ser ilustrado pelas sequências finais, construídas em elipses para o futuro e para o passado do tempo da narrativa, mas cuja montagem esclarece a formação do ethos discursivo de Michael:

- no flashback da festa surpresa de aniversário de Vito Corleone, ele revela à família que se alistou no Exército, e, logo depois, quando todos se levantam e deixam a sala para receber o pai, é o único que permanece sentado à mesa de jantar;

- isolado no escritório em Nevada, aguarda a execução do irmão no lago Tahoe, ordenada por ele;

- na última cena do filme, um travelling para frente enquadra Michael Corleone em primeiro plano, já com idade avançada (cabelos grisalhos e pele envelhecida pela maquiagem), num momento de silêncio reflexivo que tende a reforçar a ideia de reclusão. Esse movimento de câmera costuma denotar o realce do elemento dramático de passagem à interioridade da personagem e tensão mental (MARTIN, 1990, p.53).

Outra cena que permite compreender o ethos de Michael é o interrogatório ao qual ele é submetido no Senado americano, quando lê a seguinte declaração:

Na esperança de limpar o nome de minha família, de dar a meus filhos as vantagens que a América lhes deve, sem que eles se envergonhem do próprio nome, eu me apresento diante deste comitê e ofereço toda a colaboração que eu puder. Eu considero uma desonra pessoal ter que negar que eu seja criminoso. Eu gostaria que minha declaração fosse anexada aos arquivos. Servi o meu país fiel e honradamente na Segunda Guerra Mundial. Fui condecorado com a Cruz Naval pelas ações em defesa de meu país. Nunca fui preso nem acusado de nenhum crime ou delito. Não há prova de minha participação em nenhuma conspiração criminosa, seja ela a Máfia, a Cosa Nostra, ou qualquer outro nome que lhe seja dado. Nunca foi provada até hoje. Não me refugiei atrás da quinta emenda, como é meu direito. Eu desafio este comitê a produzir qualquer prova ou testemunho contra mim. Caso não consiga, espero que tenha a decência de limpar meu nome com a mesma publicidade com a qual me caluniou. 
Michael Corleone se apresenta como detentor de características honoráveis para um cidadão americano comum: colaborador da lei, pai de família com ficha civil limpa, patriota e ex-combatente condecorado da II Guerra, que não apelou para privilégios militares ao ser acusado. Assim, acredita que, não só ele, como também os seus herdeiros, possuem direitos a serem respeitados. $\mathrm{O}$ apelo às noções de honra e decência como virtudes morais evoca credibilidade. $\mathrm{O}$ uso enfático da primeira pessoa do singular, com a repetição dos pronomes eu e minha, revela a busca de fortalecimento da própria identidade como sujeito pertencente ao país que defendeu e que agora, na figura do Senado, coloca o protagonista em xeque.

A recorrência dos termos não e nunca destaca a negação das acusações para a consolidação da inocência. Convém observar que Michael Corleone também faz uso do logos, na medida em que a falta de provas e a inexistência de um passado criminal mencionadas no discurso demonstram, por conseguinte, ausência de culpa. É possível ainda identificar o recurso ao pathos na referência à família, aos filhos, aos sentimentos de vergonha e esperança.

Al Pacino confere ao protagonista um olhar sereno e lacônico, um tom de voz baixo e firme, de quem não deve e não teme. Embora o espectador tenha sido informado pela narrativa que, por trás do ethos íntegro e honesto apresentado perante o Senado, está um homem frio, calculista e poderoso, acostumado a garantir impunidade por vias escusas, o que o deixa seguro até mesmo para acusar representantes do Estado de caluniadores.

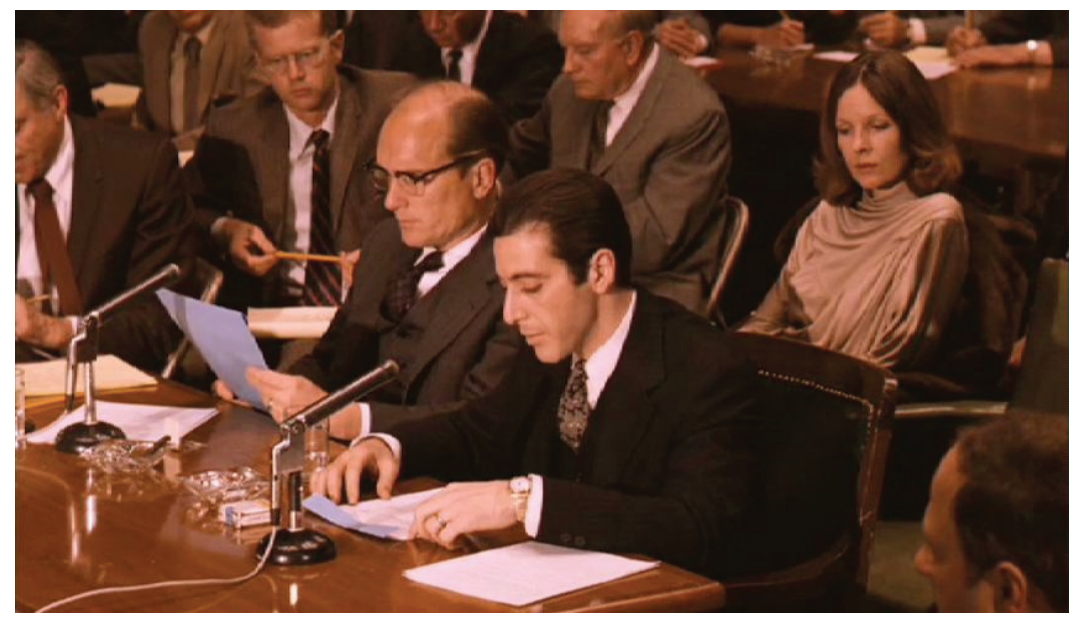

O discurso de Michael Corleone no Senado

A câmera mostra Michael em plano médio ao lado de Hagen, que acompanha a leitura com uma cópia em mãos, e a esposa Kay logo atrás, ao mesmo tempo perplexa e envergonhada. Na sequência, o enquadramento é interrompido pela imagem em primeiro plano dos senadores que comandam a sessão, e volta ainda mais fechado sobre Michael, com o rosto de Kay desfocado ao fundo. Tais aspectos da linguagem cinematográfica aproximam o espectador do universo subjetivo das personagens e agregam informações sobre o ethos discursivo analisado, na 
medida em que: Corleone aparece amparado por aqueles a quem abandonou e decepcionou; os planos e a montagem reiteram a relação de poder entre ele e a esposa, relegada das atividades criminosas e das decisões do marido.

O recurso cinematográfico à montagem paralela se destaca no estabelecimento de uma conexão entre os ethos de Vito e Michael Corleone. O diálogo entre as duas biografias e a escolha dos momentos de transição de uma para a outra favorece o estabelecimento de relações em que os ethos de ambas se misturam, adicionam características um ao outro e se diferenciam, a fim de elaborar as imagens de si de Michael e Vito, conforme acabamos de descrever em alguns pontos.

\section{Ethos de Francis Ford Coppola}

Para verficar o ethos do diretor, é preciso recorrer às informações disponíveis sobre as imagens de si de Coppola, social e individual. É ele próprio quem fornece as primeiras pistas:

Pour comprendre ce que je suis, il faudrait comprendre le petit garçon que j'étais (...) J'adorais jouer des pièces de théâtre pour mes copains, $\mathrm{j}$ 'adorais les faire jouer ensemble et je crois que je suis toujours comme ça!12 (COPPOLA apud DELORME, 2007, p.9).

Integrante de uma família ítalo-americana, Coppola nasceu em Detroit e cresceu no subúrbio de Nova Iorque. Durante a infância, passou um ano convalescente em decorrência da poliomielite, quando começou a desenvolver o espírito criativo, brincando com teatros de marionetes e uma câmera $8 \mathrm{~mm}$ que pertencia ao pai. Obteve formação em teatro e cinema, e passou a atuar como diretor, roteirista e produtor no cinema independente americano.

Em 1969, junto com nomes como George Lucas, fundou a American Zoetrope, com o objetivo de fazer concorrência a Hollywood com filmes de autor, mas projetos de difícil execução colocaram a empresa em dívida e risco. Em 1971, o jovem cineasta foi premiado com o Oscar de melhor roteiro pelo filme Patton, rebelde ou herói? (Patton, 1970) de Franklin Schaffner, e logo em seguida foi contratado pelo estúdio Paramount para a adaptação cinematográfica de $O$ Poderoso Chefão, trabalho aceito com o objetivo de usar o pagamento para salvar a produtora independente.

Mais que uma narrativa sobre a máfia, O Poderoso Chefão consiste numa crônica familiar, com as tensões e os afetos que envolvem essas relações. Não é difícil perceber no ethos a força da descendência italiana de Coppola, visível na abordagem fílmica da família e dos sentimentos, potencializados pela linguagem cinematográfica (planos, iluminação, montagem, trilha sonora, cenografia, figurino etc.).

12 Tradução livre: Para compreender quem eu sou, seria necessário compreender o pequeno garoto que eu era [...] Eu adorava representar peças de teatro para os meus amigos, colocá-los para representar juntos, e penso que até hoje sou assim! 
Minha personalidade influenciou certas cenas do filme. Claro, no filme, há conspiração, homens idealizando planos, assim como ocorreu na história do mundo, e eu, que adoro crianças, pensei: onde estão as crianças? Como será a comida? E a música? Creio que minhas preferências ou orientações vieram a combinar com o que era o tema central dos homens adultos na história. Mas também consegui incluir as coisas que eu amava, que eu pensava.

O número de identificação do menino Vito Andolini quando chega a Nova Yorque, por exemplo, é o sete, número de sorte do cineasta, que afirma sempre tentar inserir esse algarismo nos filmes que dirige. $\mathrm{O}$ desenho deixado pelo filho de Michael Corleone sobre a cama dos pais, como presente, é a reprodução de um desenho feito pelo filho de Coppola, quando criança. Na apresentação de uma versão do filme preparada para exibição em TV, Coppola esclarece ao espectador que tentou evitar os clichês e ater-se fielmente à própria memória, para que o cotidiano do lar e as emoções das personagens fossem tão autênticos como ele trazia na lembrança.

Em outras declarações, o cineasta conta que a organização frequente de encontros de integração da equipe de produção foi indispensável para dar à obra um efeito mais realista, uma aura de proximidade e cumplicidade típica das famílias italianas. Importante ressaltar também o engajamento de parentes de Coppola no projeto: o pai Carmine Coppola foi responsável pela música de cena; a irmã Talia Shire representou Connie Corleone, única mulher dentre os filhos de Vito; outros familiares participaram como figurantes. Assim, a partir daquilo que Coppola levou da própria vida para a obra e vice-versa, O Poderoso Chefão resulta num projeto discursivo impregnado pela realidade das famílias ítalo-americanas dos Estados Unidos, o que se manifesta no ethos fílmico.

\section{Considerações finais}

Embora tenhamos mencionado aqui apenas duas personagens e o diretor, já é possível visualizar indícios e perceber a complexidade e a riqueza do ethos no que concerne ao projeto discursivo cinematográfico. Quanto à orientação persuasiva do auditório via ethos, tomamos para o espectador do filme narrativo de ficção a seguinte afirmação de Amossy (1999, p.25) com relação à narrativa literária:

La question de l'ethos ne se limite pas à l'autorité et à la fiabilité de tel ou tel énonciateur. Il s'agit bien plutôt de montrer comment le récit fictionnel peut superposer différents niveaux d'interaction que ne se recouvrent pas nécessairement. Il présente en effet des narrateurs et des personnages qui construisent chacun une image de soi face à leur(s) allocutaire(s) fictionnel(s), mais aussi face au lecteur supposé. ${ }^{13}$

13 Tradução livre: A questão do ethos não se limita à autoridade e à confiabilidade de um enunciador particular. Trata-se mais de mostrar como a narrativa ficcional pode sobrepor diferentes níveis de interação que não necessariamente se encobrem. Com efeito, ela apresenta narradores e personagens que constroem, cada um, uma imagem de si perante o(s) alocutário(s) ficcional(ais), mas também diante do leitor presumido. 
Em O Poderoso Chefão II, o enredo é costurado a partir das relações entre gângsteres, em que estes revelam possuir certos princípios, ainda que controversos, e vínculos afetivos. Não há uma oposição clara entre bandido e mocinho, não existe a dicotomia do bem contra o mal nem uma lição evidente a ser retirada, comum a muitas narrativas clássicas. A caracterização do ethos analisado se associa, ao mesmo tempo, ao amor familiar, à falibilidade do ser humano, aos conflitos internos, à ambiguidade e ao relativismo da moral.

Levemos em consideração uma coenunciação que envolva $O$ Poderoso Chefão II nos dias de hoje (2013). Uma noção mínima do ethos fílmico desse objeto de troca, baseada no que acabamos de apresentar, consiste na junção entre as informações do ethos prévio da narrativa, personagens, atores, diretor; e do ethos discursivo construído ao longo do contato com o filme, em que a constituição do ethos prévio pela instância de recepção será determinante para a composição do ethos discursivo.

O filme surgiu da adaptação cinematográfica de um best seller; foi financiado por um grande estúdio, com muitos recursos; os autores são ítalo-americanos que conhecem a fundo a cultura, os costumes e as crenças desse grupo; De Niro, Pacino e Coppola são hoje vedetes consagradas no universo cinematográfico; Don Corleone tornou-se referência mítica e carismática que ultrapassou as fronteiras do cinema. O ethos fílmico resultante da comunicação com o espectador que possui esse conhecimento sobre $O$ Poderoso Chefão II difere daquele a ser produzido junto a um público que ignore esses detalhes. Este último, no entanto, também pode absorver esses elementos de alguma maneira, a partir do implícito e do explícito na materialidade discursiva fílmica.

O posicionamento da instância de recepção dependerá não só das imagens de si apresentadas pela instância de produção adicionadas ao conhecimento anterior sobre o filme, mas também do contexto da coenunciação, da identidade do espectador e das implicações no contato com a obra. Nesse sentido, ele poderá, entre outras reações: opor-se ou estar de acordo com as condutas adotadas no decorrer do filme; tomar partido de um personagem ou outro; compreender e aceitar ou não os motivos que levam a atitudes consideradas imorais (ou amorais); aplicar ou não ao próprio cotidiano as opiniões adquiridas em função da narrativa.

O impacto do ethos estará vinculado aos efeitos das outras provas retóricas sobre o coenunciador. Componentes subjetivos desse indivíduo, tais como a origem, a profissão, a posição social, a religião ou a formação também exercerão influência sobre a apreensão do ethos fílmico, bem como das demais dimensões argumentativas possíveis. Assim, a verificação do ethos nesse tipo de projeto discursivo revela-se como um instrumento eficiente para o exame do potencial persuasivo de um determinado filme narrativo de ficção.

\section{$\overline{\text { REFERÊNCIAS BIBLIOGRÁFICAS }}$}

AMOSSY , R. Les idées reçues - Sémiologie du stéréotype. Paris: Éditions Nathan, 1991. 
. La notion d'ethos de la rhétorique à l'analyse de discours. In: AMOSSY, Ruth. (sous la direction de) Images de soi dans le discours: la construction de l'ethos. Lausanne: Delachaux et Niestlé, 1999. p. 9-30. . L'argumentation dans le discours. Paris: Armand Colin, 2006.

ARISTÓTELES. Retórica. Tradução e notas de Manuel Alexandre Júnior. Estudos Gerais - Série universitária - Clássicos da filosofia. Lisboa: Imprensa Nacional Casa da Moeda, 2000.

CHARAUDEAU, P. Uma Teoria dos Sujeitos da Linguagem. In: MARI, H.; MACHADO, I.; MELLO, R. (orgs.). Análise do Discurso: Fundamentos e Práticas. Belo Horizonte: NAD/FALE/UFMG, 2001, p. 23-38.

COSTA, A. Compreender o cinema. São Paulo, Globo: 1989.

DELORME, S. Le livre Francis Ford Coppola. Paris: Cahiers du cinéma, Collection Grands Cinéastes, 2007.

DUNCAN, P. (org.) The Godfather family album - photographs by Steve Schapiro. Taschen: Colônia, 2010.

EGGS, E. Ethos aristotélicien, conviction et pragmatique moderne. In: AMOSSY, Ruth. (sous la direction de) Images de soi dans le discours: la construction de l'ethos. Lausanne: Delachaux et Niestlé, 1999. p. 31-59.

MARTIN, M. A linguagem cinematográfica. São Paulo: Brasiliense, 1990.

PAVEAU, M-A.; SARFATI, G-É. As grandes teorias da linguística - da gramática comparada à pragmática. São Carlos: Claraluz, 2006.

O PODEROSO Chefão - The Coppola Restoration (The Godfather). Direção: Francis Ford Coppola. São Paulo: Paramount Pictures. 2008. 4DVDs, widescreen, color., legendado.

OLBRECHTS-TYTECA, L.; PERELMAN, C. Traité de l'argumentation - la nouvelle rhétorique. Bruxelas: Editions de 1'Université de Bruxelles, 2008. $6^{\mathrm{a}}$ ed. 